\title{
SYNTHESIS AND CHARACTERIZATION OF NIOBIUM AND TUNGSTEN SUBSTITUTED VOPO
}

\author{
SUBRATA CHANDRA ROY*, LILUFER YEASMIN AND MAHMUDUR RAHMAN \\ Department of Chemistry, Jagannath University, Dhaka-1100, Bangladesh
}

\begin{abstract}
Tungsten and Niobium substituted $\alpha_{\mathrm{II}}-\mathrm{VOPO}_{4}$ structure type solid solution $\left(\mathrm{V}_{1-x-y} \mathrm{~W}_{x} \mathrm{Nb}_{\mathrm{y}}\right) \mathrm{OPO}_{4}$ where $x=0.07$ and $y \leq 0.05$ was synthesized by solution combustion technique followed by heating in air at $700^{\circ} \mathrm{C}$ for 3 days. Further incorporation of niobium $(\mathrm{y}>0.05)$ leads to a mixture of $\alpha_{\mathrm{II}}-\mathrm{VOPO}_{4}$ structure type solid solution and two very weak reflections of another unknown phase. The synthesized product was characterized by X-ray powder diffraction, SEM/EDX, FTIR, and magnetic property analysis.
\end{abstract}

Keywords: solid solution, heterogeneous catalyst, x-ray powder diffraction

\section{INTRODUCTION}

For the period of last decades Vanadyl pyrophosphate, $(\mathrm{VO})_{2} \mathrm{P}_{2} \mathrm{O}_{7}$ (VPP) has been comprehensively studied due to its exceptional catalytic properties for the selective oxidation of $n$-butane to maleic anhydride (MA, furan-2,5dione) (Bordes et al. 1979 and Schlögl 2009, eq. 1). The importance of MA can well be understood by its huge annual production of 2.7 million tons (Trifiro et al. 2014). The catalytic behavior of VPP is attributed to its exceptional physicochemical properties and crystal structure (Fig. 1).

$$
\begin{array}{r}
\mathrm{n}-\mathrm{C}_{4} \mathrm{H}_{10}+7 / 2 \mathrm{O}_{2} \stackrel{\text { vPP }}{\longrightarrow} \mathrm{C}_{2} \mathrm{H}_{2}(\mathrm{CO})_{2} \mathrm{O}+4 \mathrm{H}_{2} \mathrm{O} ; \\
\Delta \mathrm{H}=-1236 \mathrm{KJ} / \mathrm{mol}
\end{array}
$$

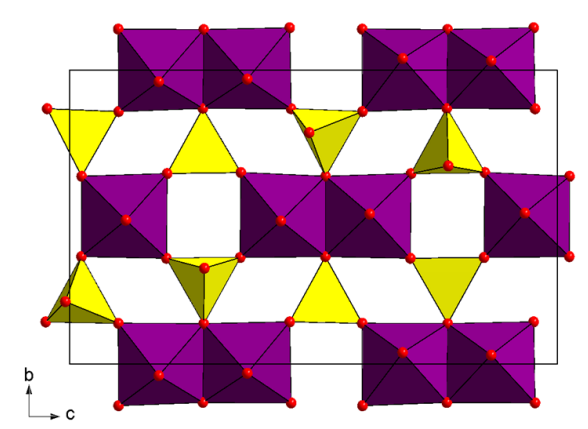

Fig. 1. Crystal structure of $(\mathrm{VO})_{2} \mathrm{P}_{2} \mathrm{O}_{7}$ (Hiroi et al.1999), deep $\mathrm{V}_{2} \mathrm{O}_{10}$ edge-sharing dioctahedra, light $\mathrm{P}_{2} \mathrm{O}_{7}$ groups.

\footnotetext{
*Corresponding author: <scroy1979@yahoo.com>.
}

The true chemical composition and the structural properties of the active site of VPP for this catalytic reaction under operando conditions are still under debate (Hutching et al. 1998 and Hodnett 2000). Scientists are trying to explore the mystery of this complicated catalytic reaction process. However, this catalyst shows a conversion and yield of about $85 \%$ and $65 \%$ (Ballarini 2006), respectively. It was shown that an amorphous surface layer on crystalline $(\mathrm{VO})_{2} \mathrm{P}_{2} \mathrm{O}_{7}$ might be the active phase (Zazhigalov $1983)$. The existence of other polymorphs $\left(\alpha_{\mathrm{II}^{-}}\right.$, $\beta-, \gamma-, \delta-, \omega-)$ of $\mathrm{V}^{\mathrm{V}} \mathrm{OPO}_{4}$ were also confirmed by in-situ spectroscopic and diffraction studies (Hutching et al. 1994, Hutching et al. 1996, and Conte et al. 2006) This can be attributed to the oxidation of VPP as shown in eq. 2 .

$$
(\mathrm{VO})_{2} \mathrm{P}_{2} \mathrm{O}_{7}+0.5 \mathrm{O}_{2} \rightarrow 2 \mathrm{VOPO}_{4} \quad \text { (eq. 2) }
$$

Scientists are yet to modify the existing catalyst by adding promoters or dopants, since there is enough opportunity to improve the yield of MA. However, studies on incorporation of catalytic promoters did not lead to an improved catalyst activity and selectivity (Agaskar et al. 1997, Davis et al. 2002, Guliants et al. 1999, Rownaghi et al. 2009). Recently it was reported that the catalytic activity and selectivity of various, polynaryvanadium (IV) phosphates 
containing a transition metal $(\mathrm{Cr}, \mathrm{Fe}, \mathrm{Ni}, \mathrm{Cu})$ in the phosphate framework do not reach the conventional VPP catalyst (Glaum et al. 2007 and Benser et al. 2007).

P. K. Grasselli (2002) reported that redox active transition metals with oxidation states are vanadium (IV, V), iron (II, III), copper (I, II), manganese (III, IV), molybdenum (V, VI), and rhenium (IV, V, VI, VII), niobium (IV, V) which could be potential components of oxidation catalyst materials. Aiming at the inclusion of mixed-valency in $\alpha_{\mathrm{II}}-\mathrm{VOPO}_{4}$ by solid solution formation with $\left(\mathrm{V}^{\mathrm{IV}} \mathrm{O}\right) \mathrm{Mo}^{\mathrm{VI}} \mathrm{O}_{4}$ or $\left(\mathrm{Mo}^{\mathrm{V}} \mathrm{O}\right) \mathrm{PO}_{4}$ led to $7 \%$ of heterovalent substitution of $\mathrm{PO}_{4}$ by $\mathrm{MoO}_{4}$ and $\mathrm{V}^{5+}$ by $\mathrm{V}^{4+}$ (Raminosona et al. 1987). On the other hand, substitution of "Nb" by "W" in $\alpha-\mathrm{NbOPO}_{4}$, S.G. $P 4 / n$ (Longo et al. 1996) lead to $\left(\mathrm{Nb}_{0.787} \mathrm{~W}_{0.213}\right) \mathrm{OPO}_{4}$, S.G. P4/nmm (Leclaire et al. 1997) which is very much related to the host structure. It is worth to be mentioned that the high temperature polymorph $\beta-\mathrm{NbOPO}_{4}$ (Leclaire et al. 1986) is isotypic to $\mathrm{WOPO}_{4}$ (Wang et al. 1989, and Roy et al. 2016). However, information on solid solution formation among $\mathrm{VOPO}_{4} \mathrm{NbOPO}_{4}$ and $\mathrm{WOPO}_{4}$ were lacking in literature. This might be attributed to their different crystal structures and the quite different redox behavior of $\mathrm{V}^{5+}, \mathrm{Nb}^{5+}$ and $\mathrm{W}^{5+}$.

Here the synthesis and characterization of solid solution of polynaryphosphate, $\left(\mathrm{V}_{1-x-y} \mathrm{~W}_{x} \mathrm{Nb}_{\mathrm{y}}\right)$ $\mathrm{OPO}_{4}\left(\alpha_{I I^{-}}-\mathrm{VOPO}_{4}\right.$ type); where $x=0.07$ and $0 \leq$ $y \leq 0.15$ is reported. This solid solution allows to incorporation of a third redox active transition metal center "Nb" besides "V" and "W". $\alpha_{I I}-\mathrm{VOPO}_{4}$ structure could be stabilized by substitution of vanadium by tungsten in the range of $0.04 \leq x \leq 0.24$ (Roy et al. 2014). Moreover, partial substitution of "V" by "W" in $\alpha_{I I}-\mathrm{VOPO}_{4}$ leads to promising catalyst material for butane based oxidation (Schulz et al. 2018). Therefore to attain the $\alpha_{I I}-\mathrm{VOPO}_{4}$ structure type solid solution the amount of "W" in the aiming product is taken 0.07 .

\section{MATERIALS AND METHODS}

Synthesis of solid solution of

polynaryphosphates.

The aimed $\alpha_{I I}-\mathrm{VOPO}_{4}$ structure type solid solution of polynaryphosphates, $\left(\mathrm{V}_{1-x}\right.$ $\left.{ }_{y} \mathrm{~W}_{x} \mathrm{Nb}_{\mathrm{y}}\right) \mathrm{OPO}_{4}$ where $x=0.07$ and $0 \leq y \leq 0.15$ were synthesized by solution combustion synthesis, SCS (Patil et al. 1997 and Moore et al. 1995) followed by heating the reaction intermediates after combustion in air up to $700{ }^{\circ} \mathrm{C}$ according to eq. 3 .

$$
\begin{array}{lr}
\mathrm{x} / 12\left(\mathrm{NH}_{4}\right)_{6} \mathrm{~W}_{12} \mathrm{O}_{39}+\mathrm{y}\left(\mathrm{NH}_{4}\right) \mathrm{NbOC}_{4} \mathrm{O}_{8}+(1-\mathrm{x}- \\
\mathrm{y}) \mathrm{NH}_{4} \mathrm{VO}_{3}+\left(\mathrm{NH}_{4}\right)_{2} \mathrm{HPO}_{4} \rightarrow\left(\mathrm{V}_{1-x-x} \mathrm{Nb}_{y}\right) \mathrm{OPO}_{4} \\
+\mathrm{CO}_{2}+\mathrm{H}_{2} \mathrm{O}
\end{array}
$$

Appropriate amount of precursor materials: ammonium metatungstate $\left[\left(\mathrm{NH}_{4}\right)_{6} \mathrm{~W}_{12} \mathrm{O}_{39}\right.$ $\left.5.21 \mathrm{H}_{2} \mathrm{O}\right]$, ammonium niobate $(\mathrm{V})$ oxalate $\left[\left(\mathrm{NH}_{4}\right)\right.$ $\left.\mathrm{NbOC}_{4} \mathrm{O}_{8} \cdot 0.59 \mathrm{H}_{2} \mathrm{O}\right]$, diammonium hydrogen phosphate $\left[\left(\mathrm{NH}_{4}\right)_{2} \mathrm{HPO}_{4}\right]$, and ammonium metavanadate $\left[\left(\mathrm{NH}_{4}\right) \mathrm{VO}_{3}\right]$ (all from Sigma Aldrich, p.a) were dissolved in minimum amount of water together with oxidizer $\left(\mathrm{HNO}_{3}\right)$ and fuel (glycine) with continuous stirring as described in Roy et al. 2014.

\section{$X$-ray powder Diffraction analysis}

The X-ray powder patterns of the samples $\left(\mathrm{V}_{1-x-y} \mathrm{~W}_{x} \mathrm{Nb}_{y}\right) \mathrm{OPO}_{4}$ were taken by Rigaku Ultima IV diffractometer at the Centre for Advanced Research Centre, (CARS) University of Dhaka, Bangladesh. The operating conditions of the diffractometer were $40 \mathrm{kV}, 40 \mathrm{~mA}, \mathrm{Cu}-\mathrm{K} \alpha_{1}$ radiation $\left(\lambda=1.54051^{\circ}\right)$, exposure time $3 \mathrm{deg} /$ minute.

\section{SEM and EDX analysis}

Scanning Electron Microscopic and Energy Dispersive X-ray analysis were carried out by Zeiss Evo 18 (operated at $10 \mathrm{kV}$ ) and EDAX, respectively from Bangladesh Council of Science and Industrial Research (BCSIR), Dhaka-1205, Bangladesh. The sample was sputtered with gold before EDX analysis and three different areas of the sample were focused with electron beam to get the average elemental composition. 


\section{Magnetic measurements}

The mass magnetic susceptibility of the powder sample was measured by magnetic susceptibility balance MARK 1, (Sherwood Scientific Ltd., Cambridge) at Jagannath University, Dhaka1100, Bangladesh using the eq. 4.

$$
X_{g}=C \cdot \frac{I}{m} \cdot \frac{\left(R-R_{0}\right)}{10^{9}}
$$

Where, $l=3 \mathrm{~cm}$ (length of sample on sample holder); $\mathrm{m}=0.241 \mathrm{~g}$, mass of the sample; $\left(\mathrm{R}-\mathrm{R}_{0}\right)=7-(-29)$, difference between balance reading for the sample holder tube with sample and without sample; $\mathrm{C}=957.08 \times 10^{-6}$, proportionality constant.

\section{FTIR analysis}

The FTIR analysis was carried out by Shimadzu IR Tracer-100 at Jagannath University, Dhaka1100, Bangladesh. The powder sample was mixed and ground with highly purified $\mathrm{KBr}$ (p.a.) as approximate 10:1 ratio in a clean agate mortar to a fine powder. Transparent discs from that mixture were prepared by manual pressing. All the infrared transmission spectra were determined at room temperature in the range of wave number 400 to $4000 \mathrm{~cm}^{-1}$.

\section{RESULTS AND DISCUSSION}

X-ray powder diffraction patterns of powder samples show single-phase solid solution $\left(\mathrm{V}_{1-x} \mathrm{~W}_{x} \mathrm{Nb}_{y}\right) \mathrm{OPO}_{4}$ where $x=0.07$ and $0.0 \leq y \leq$ 0.05 with $\alpha_{\mathrm{II}}-\mathrm{VOPO}_{4}$ structure type (Fig. 2.). Further incorporation of niobium $0.05<\mathrm{y} \leq 0.15$ leads to two very weak diffraction peaks of unknown phase. With increasing the niobium concentration the intensity of unknown phase increases but it is very little. Due to small number of diffraction peaks as well very low intensity, they are not possible to index.

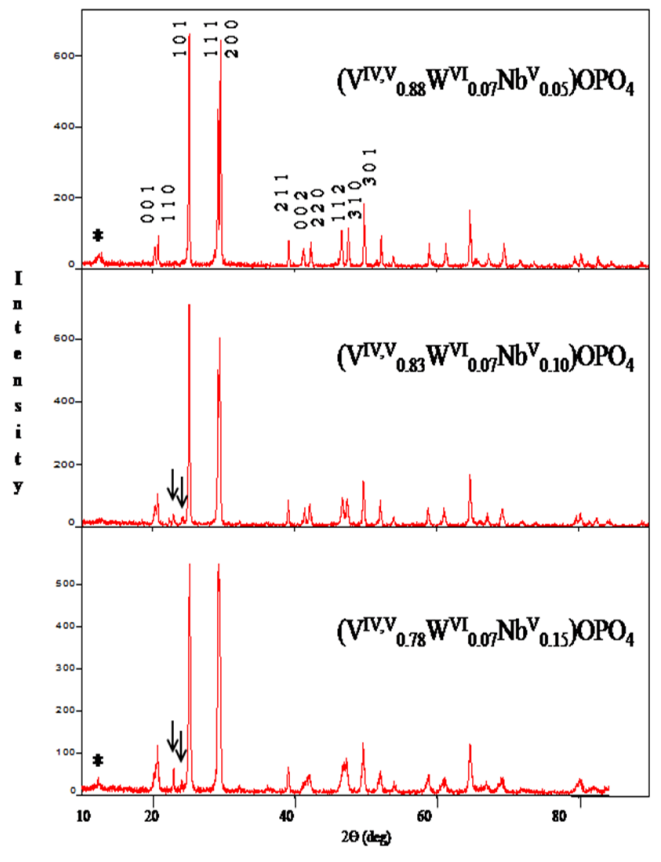

Fig. 2. Comparison of X-ray powder diffraction patterns of members of the solid solutions $\left(\mathrm{V}_{1-x-y} \mathrm{~W}_{x} \mathrm{Nb}_{y}\right) \mathrm{OPO}_{4}$ (with $x=0.07$ and $0.0 \leq \mathrm{y} \leq$ 0.15 ) where $0.0 \leq y \leq 0.05$ is only $\alpha_{\mathrm{II}}-\mathrm{VOPO}_{4}$ structure type, and y>0.05 is mixture $\alpha_{\mathrm{II}}-\mathrm{VOPO}_{4}$ structure type solid solution and an unknown phase (indicated by down arrows). Asterisks are $\mathrm{VOPO}_{4} \cdot 2 \mathrm{H}_{2} \mathrm{O}$ type phase due to hydration of $\left(\mathrm{V}_{0.88} \mathrm{~W}_{0.07} \mathrm{Nb}_{0.05}\right) \mathrm{OPO}_{4}$ in lab condition.

Exposure of solid solution $\left(\mathrm{V}_{1-x-y} \mathrm{~W}_{x} \mathrm{Nb}_{y}\right) \mathrm{OPO}_{4}$, with $\alpha_{\mathrm{II}}-\mathrm{VOPO}_{4}$ structure type to lab atmosphere over a period of several days led to their hydration, as it is suggested by the XRPD pattern of the phases (Fig. 2., indicated by asterisk), which is very similar to the one observed for $\left(\mathrm{V}_{1-x} \mathrm{~W}_{x}\right) \quad \mathrm{OPO}_{4} \cdot 2 \mathrm{H}_{2} \mathrm{O}$ and $\mathrm{VOPO}_{4} \cdot 2 \mathrm{H}_{2} \mathrm{O}$ (Roy et al. 2014, and Tietze 1981). The layer type structure of $\left(\mathrm{V}_{0.88} \mathrm{~W}_{0.07} \mathrm{Nb}_{0.05}\right)$ $\mathrm{OPO}_{4}\left(\alpha_{\mathrm{II}}-\mathrm{VOPO}_{4}\right.$ structure type, (Fig. 3) allows the incorporation of water molecules as guest species between the layers of the host structure. 


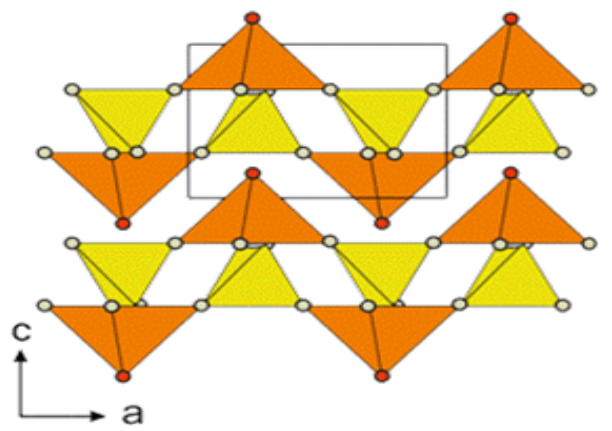

Fig. 3. Polyhedral representation of $\left(\mathrm{V}_{0.88} \mathrm{~W}_{0.07} \mathrm{Nb}_{0.05}\right) \mathrm{OPO}_{4}\left(\alpha_{\mathrm{II}}-\mathrm{VOPO}_{4}\right.$ type). [MO $]$ square pyramids $(\mathrm{M}=\mathrm{V} / \mathrm{W} / \mathrm{Nb})$ : deep, $\left[\mathrm{PO}_{4}\right]$ tetrahedra: light, filled circles represent oxygen atoms of $(\mathrm{M}=\mathrm{O})^{3+}$.

Immediately after ignition at $400^{\circ} \mathrm{C}$ for five minutes the XRPD pattern of the combustion product shows reflections of Keggin type structure, $\left(\mathrm{NH}_{4}\right)_{3} \mathrm{PW}_{12} \mathrm{O}_{40} \cdot 9.5 \mathrm{H}_{2} \mathrm{O}$ (Zubkov 1998) as shown in Fig. 4. Further heating (stepwise upto $600^{\circ} \mathrm{C}$ ) of the material after grinding in an agate mortar shows the same phase. The aimed solid solution $\left(\mathrm{V}_{0.88} \mathrm{~W}_{0.07} \mathrm{Nb}_{0.05}\right) \mathrm{OPO}_{4}$ is obtained at $700^{\circ} \mathrm{C}$ for 3 days.

The formation of Keggin type structure, $\left(\mathrm{NH}_{4}\right)_{3} \mathrm{PW}_{12} \mathrm{O}_{40} \cdot 9.5 \mathrm{H}_{2} \mathrm{O}$ prior to the occurrence of aimed solid solution, $\left(\mathrm{V}_{0.88} \mathrm{~W}_{0.07} \mathrm{Nb}_{0.05}\right) \mathrm{OPO}_{4}$ $\left(\alpha_{\mathrm{II}}-\mathrm{VOPO}_{4}\right.$ structure type $)$ is obvious.

IR spectrum Fig. 5 shows that a weak peak at $1091 \mathrm{~cm}^{-1}$ which corresponds to the asymmetric stretching vibration of the $\mathrm{PO}_{4}$ tetrahedra, while the peak at $921 \mathrm{~cm}^{-1}$ can be assigned to the symmetric stretching vibration of the $\mathrm{PO}_{4}$ tetrahedra (R'kha et al. 1986). In addition, the peaks at $534 \mathrm{~cm}^{-1}$ and $427 \mathrm{~cm}^{-1}$ reflect the bending vibration of the $\mathrm{PO}_{4}$ tetrahedra. Symmetric stretching mode of $\mathrm{M}=\mathrm{O}$ (M: $\mathrm{V} / \mathrm{Nb} / \mathrm{W}$ ) of vanadyl group was observed at 968 $\mathrm{cm}^{-1}$ (Barraclough et al. 1959). Furthermore, the sharp peaks close to 605 , and $628 \mathrm{~cm}^{-1}$ can be

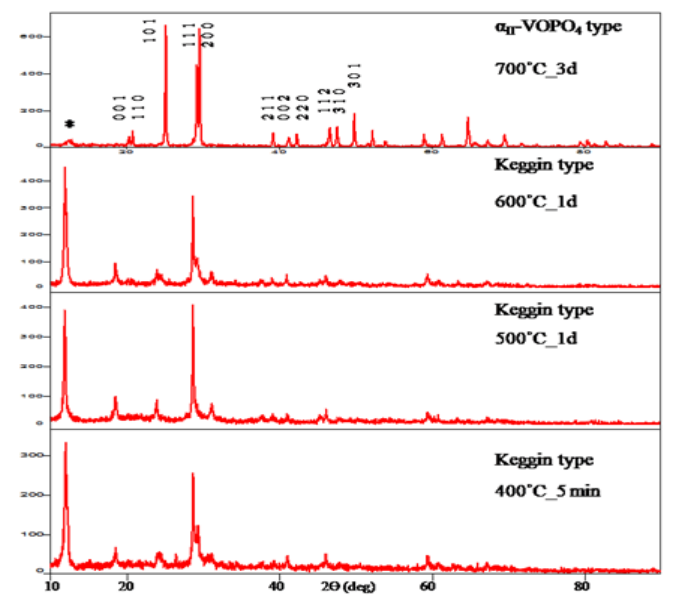

Fig. 4. Powder diffraction patterns $\left(\mathrm{V}_{0.88} \mathrm{~W}_{0.07} \mathrm{Nb}_{0.05}\right) \mathrm{OPO}_{4}$, showing the progress of phase formation with temperature by heating in air. Asterisks are $\mathrm{VOPO}_{4} \cdot 2 \mathrm{H}_{2} \mathrm{O}$ type due to hydration of $\left(\mathrm{V}_{0.88} \mathrm{~W}_{0.07} \mathrm{Nb}_{0.05}\right) \mathrm{OPO}_{4}$ in lab condition.

attributed to the $\mathrm{M}-\mathrm{O}$ bending vibrations in $\mathrm{MO}_{6}$ octahedra. The weak and broad band at 3527 and $1635 \mathrm{~cm}^{-1}$ arises from the $\mathrm{O}-\mathrm{H}$ bond stretching modes and $\mathrm{HOH}$ bending modes, respectively. Weak band at $686 \mathrm{~cm}^{-1}$ corresponds to bending vibration modes of $(\mathrm{M}-\mathrm{OH})$ or $(\mathrm{P}-\mathrm{OH})$. The incorporation of water molecule is also confirmed by XRPD (Fig. 2.) as hydration of $\left(\mathrm{V}_{0.88} \mathrm{~W}_{0.07} \mathrm{Nb}_{0.05}\right) \mathrm{OPO}_{4}$ led to formation of $\left(\mathrm{V}_{0.88} \mathrm{~W}_{0.07} \mathrm{Nb}_{0.05}\right) \mathrm{OPO}_{4} \cdot 2 \mathrm{H}_{2} \mathrm{O}$.

The magnetic measurement of the powder sample of $\left(\mathrm{V}_{0.88} \mathrm{~W}_{0.07} \mathrm{Nb}_{0.05}\right) \mathrm{OPO}_{4}$ reveals the paramagnetic behavior. The measured mass susceptibility, $\chi_{g}$ (at room temperature, $28^{\circ} \mathrm{C}$ ) is $428.90 \times 10^{-9} \mathrm{~cm}^{3} \mathrm{~g}^{-1}$ and the molar magnetic susceptibility, $\chi_{\mathrm{mol}}$ is $112.41 \times 10^{-6} \mathrm{~cm}^{3} \mathrm{~mol}^{-1}$. Roy et al. reported (2014) that incorporation of $\mathrm{W}^{6+}$ in $\alpha_{\mathrm{II}}-\mathrm{V}^{\mathrm{V}} \mathrm{OPO}_{4}$ led reduction of $\mathrm{V}^{5+}$ to $\mathrm{V}^{4+}$ according to $\quad\left(\mathrm{V}_{0.24}^{\mathrm{IV}} \mathrm{V}_{0.52} \mathrm{~W}_{0.24} \mathrm{VI}_{0} \mathrm{OPO}_{4}\right.$. Therefore, paramagnetic property of $\left(\mathrm{V}_{0.88} \mathrm{~W}_{0.07} \mathrm{Nb}_{0.05}\right) \mathrm{OPO}_{4}$ can be attributed to the presence of tetravalent vanadium as $\left(\mathrm{V}^{\mathrm{IV}}{ }_{0.07} \mathrm{~V}_{0.81} \mathrm{~W}_{0.07} \mathrm{Nb}_{0.05}\right) \mathrm{OPO}_{4}$. 


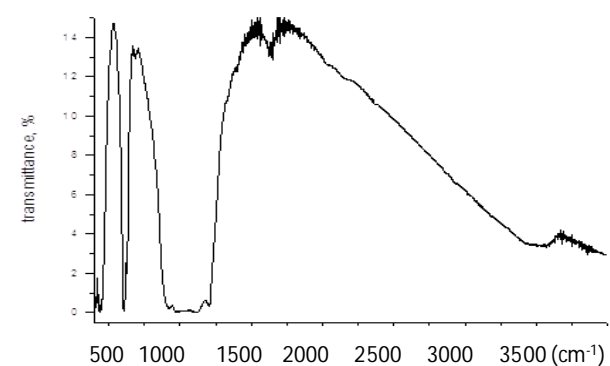

Fig. 5. FTIR spectrum of solid solution $\left(\mathrm{V}_{0.88} \mathrm{~W}_{0.07} \mathrm{Nb}_{0.05}\right) \mathrm{OPO}_{4} \quad\left(\alpha_{\mathrm{II}}-\mathrm{VOPO}_{4}\right.$ type $)$ with $\mathrm{KBr}$.

The SEM image of $\left(\mathrm{V}_{0.88} \mathrm{~W}_{0.07} \mathrm{Nb}_{0.05}\right) \mathrm{OPO}_{4}$ (Fig. 6a) shows crystallites with homogeneous morphology which indicates all the crystallites contain same type of elements. The EDX result shows no hints on impurity elements (Fig. 6b) and the average atomic $(\%)$ ratio of $\mathrm{V}: \mathrm{W}: \mathrm{Nb}: \mathrm{P}=$ 46.1:2.4:2.0:49.5 which is close to the nominal composition 44.0:3.5:2.5:50.0, respectively.
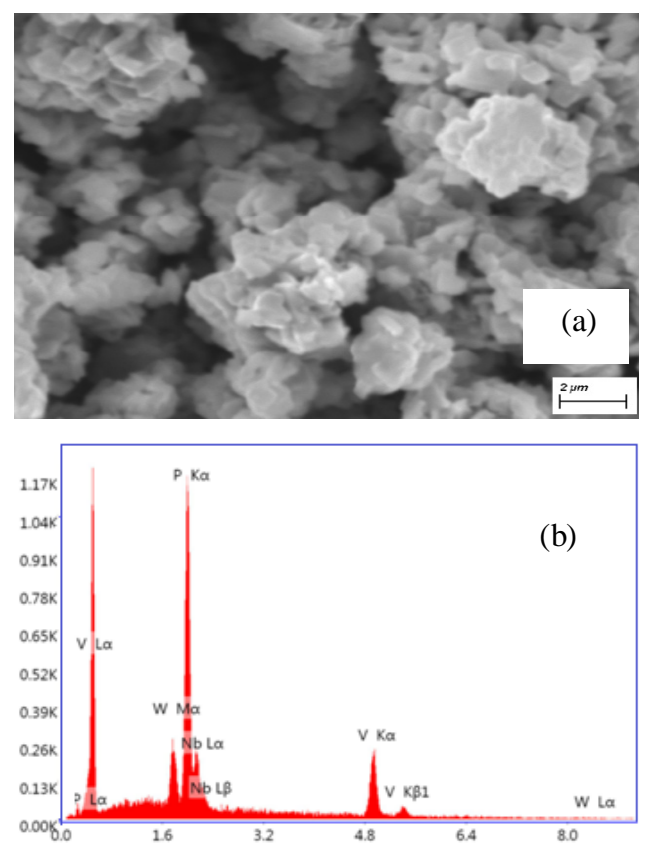

Fig. 6. SEM image (a), and EDX spectrum (b), of $\left(\mathrm{V}_{0.88} \mathrm{~W}_{0.07} \mathrm{Nb}_{0.05}\right) \mathrm{OPO}_{4}$.

\section{CONCLUSION}

Pure $\mathrm{VOPO}_{4}$ is catalytically dead for the partial oxidation of n-butane to maleic anhydride however, only tungsten substituted $\mathrm{VOPO}_{4},\left(\mathrm{~V}_{1-x} \mathrm{~W}_{x}\right) \mathrm{OPO}_{4}$; where $0 \leq x \leq 0.24$ $\left(\alpha_{\mathrm{II}}-\mathrm{VOPO}_{4}\right.$ structure type) [Schulz et al. 2018] leads to a new catalyst material for that purpose. Since the insertion of another redox active transition metal, niobium in presence of tungsten might increase this catalytic efficiency. Therefore, the niobium and tungsten substituted $\alpha_{\mathrm{II}}-\mathrm{VOPO}_{4}$ type solid solution $\left(\mathrm{V}_{1-x-y} \mathrm{~W}_{x} \mathrm{Nb}_{\mathrm{y}}\right)$ $\mathrm{OPO}_{4}$; where $x=0.07$ and $y \leq 0.05\left(\alpha_{\mathrm{II}}-\mathrm{VOPO}_{4}\right.$ structure type) was synthesized by solution combustion technique followed by heating in air at $700^{\circ} \mathrm{C}$ for 3 days. The metanyl bond $(M=\mathrm{O}$; $M: \mathrm{V}, \mathrm{Nb}, \mathrm{W})$ and bonds in $\mathrm{PO}_{4}$ were confirmed by FTIR spectrum. The paramagnetic behavior of the synthesized product indicates the presence of tetravalent vanadium and EDX analysis showed the incorporation of both tungsten and niobium in $\alpha_{\mathrm{II}}-\mathrm{VOPO}_{4}$ structure type phase.

\section{ACKNOWLEDGMENT}

S.C. Roy gratefully acknowledges a Jagannath University Research Grant for financial support. All authors are thankful to reviewer/s for helpful comments.

\section{REFERENCES}

Agaskar P. A., P. K. Grasselli, D. J. Buttrey and B. White. 1997. Structural and catalytic aspects of some NASICON - based mixed metal phosphates, Stud. Surf. Sci. Catal., 110: $219-226$.

Ballarini N., F. Cavani, C. Cortelli, S. Ligi, F. Pierelli, F. Trifiro, C. Fumagalli, G. Mazzoni and T. Monti. 2006. VPO catalyst for $n$-butane oxidation to maleic anhydride: A goal achieved, or a still open challenge? Top. Catal. 38: 147-156. 
Barraclough C. G., J. Lewis, and R. S. Nyholm. 1959. The stretching frequencies of metaloxygen double bonds, J. Chem. Soc., p35523555 .

Bordes E. and P. Courtine. 1979. Some selectivity criteria in mild oxidation catalysis: VPO phases in butene oxidation to maleic anhydride, J. Catal 57: 236-252.

Conte M., G. Budroni, J. K. Bartley, S. H. Taylor, A. F. Carley, A. Schmidt, D. M. Murphy, F. Girgsdies, T. Ressler, R. Schlögl and G. J. Hutchings. 2006. Chemically Induced Fast Solid-State Transitions of $\omega$ $\mathrm{VOPO}_{4}$ in Vanadium Phosphate Catalysts, Science 313: 1270-1273.

Davis M. E., C. J. Dillon, J. H. Holles and J. Labinger. 2002. A New Catalyst for the Selective Oxidation of Butane and Propane, Angew. Chem. Int. Ed., 41: 858-860.

Glaum R., E. Benser and H. Hibst. 2007. Novell Ternary and Polynary Vanadium (IV) Phosphates as Catalysts for Selective Oxidations of Light Hydro-carbons, Chem. Ing. Tech 79: 843-850

Grasselli P. K., 2002, Fundamental Principles of Selective Heterogeneous Oxida-tion Catalysis, Top. Catal., 21:79-88.

Guliants V. V, J. B. Benziger, S. Sundaresan, I. E. Wachs and A. M. Hirt. 1999. Cat. Lett., 62: 87-91.

Hiroi Z, M. Azuma, Y. Fujishiro, T. Saito, M. Takano, F. Izumi, T. Kamiyama and T. Ikeda. 1999. Structural Study of the Quantum-Spin Chain Compound $(\mathrm{VO})_{2} \mathrm{P}_{2} \mathrm{O}_{7}$, J. Solid State Chem., 146: 369379.

Hodnett B. K. 2000. Heterogeneous Catalytic Oxidation, John Wiley \& Sons, Chichester.

Hutchings G. J., A. Desmartin-Chomel, R. Oller and G. J. Volta. 1994, Role of the product in the transformation of a catalyst to its active state, Nature, 368: 41-45.
Hutchings G. J., C. J. Kiely, M. T. S. Schulz, A. Burrows and J.-C. Volta. 1998. Comments on the nature of the active site of vanadium phosphate catalysts for butane oxidation, Catal. Today, 40: 273-286.

Hutchings G. J., I. J. Ellison, M. T. Sananes and J.C. Volta 1996, Catal. Lett. 38: 231-237.

Leclaire A., M. M. Borel and B. Raveau. 1997. Combination of $\alpha-\mathrm{NbOPO}_{4}$ type layers with enantiomorphic $\alpha^{\prime}$-type layers: the "racemic structure" of $\alpha-\alpha^{\prime}-\mathrm{Nb}_{0.787} \mathrm{~W}_{0.213} \mathrm{OPO}_{4}, \quad Z$. Kristallogr., 212: 837-839 .

Leclaire A., H. Chahboun, D. Groult and B. Raveau. 1986. The crystal structure of B$\mathrm{NbPO}_{5}$, Z. Kristallogr. 177: 277-286.

Longo J. M. and P. Kierkegaard. 1966. The crystal structure of $\mathrm{NbOPO}_{4}$, Acta Chem. Scand. 20: 72-78.

Moore J. J. and H. J. Feng. 1995. Combustion synthesis of advanced materials: Part I. Reaction parameters, Prog. Mater. Sci., 39: 243-273.

Moore J. J. and H. J. Feng. 1995. Combustion synthesis of advanced materials: Part II. Classification, applications and modeling, Prog. Mater. Sci. 39: 275-316.

Patil K. C., S. T. Aruna and S. Ekambaram. 1997. Combustion Synthesis, Current Opinion Sol. St. Mat. Sci., 2. 158-165.

Raminosona A., E. Bordes and P. Courtine. 1987. Molybdenum-doped V-P-O system: I. Preparation and characteri-zation, J. Solid State Chem., 68: 1-10.

R'Kha C., M. T. Vandenborre and J. Livage. 1986, Spectroscopic study of colloidal $\mathrm{VOPO}_{4} \cdot 2 \mathrm{H}_{2} \mathrm{O}$, J. Solid State Chem., 63: 202-215.

Rownaghi A. A., Y. H. T. Yap and F. Rezaei. 2009. Influence of rare-earth and bimetallic promoters on various VPO catalysts for partial oxidation of n-butane, Cat. Lett, 130: 504-516. 
Roy S. C., W. Assenmacher, T. Linden, L. Esser, W. Mader and R. Glaum. 2016. Substitution of $\mathrm{W}^{5+}$ in Monophosphate Tungsten Bronzes by Combinations $M^{\mathrm{n}+} / \mathrm{W}^{6+}, \mathrm{Z}$. für Naturforschung B 71: 543-552.

Roy S. C., R. Glaum, D. Abdullin, O. Schiemann, N. Q. Bac and K-W. Lii. 2014. Solid Solution Formation between Vanadium(V) and Tungsten(V) Oxide Phosphate, Z. Anorg. Allg. Chem., 640: 1876-1885.

Schlögl R., 2009, Modern Heterogenous Oxidation Catalysis (Ed: N. Mizuno), Wiley $\mathrm{VCH}$, Weinheim.

Schulz C., S. C. Roy, K .Wittich, R. N. d'Alnoncourt, S. Linke, V. Strempel. B. Frank, R. Glaum and F. Rosowski. 2018. $\alpha_{\mathrm{II}}-\left(\mathrm{V}_{1-x} \mathrm{~W}_{x}\right) \mathrm{OPO}_{4}$ catalysts for the selective oxidation of $n$-butane to maleic anhydride, Catal. Today, in press, https: //doi.org/10. 1016/j.cattod. 2018.05.040.

Tietze H. R., 1981. The crystal and molecular structure of oxovanadium (V) orthophosphate dihydrate, $\mathrm{VOPO}_{4} \cdot 2 \mathrm{H}_{2} \mathrm{O}$ Aus. J. Chem. s34: 2035-2038.
Trifiro F. and P. K. Grasselli. 2014. How the Yield of Maleic Anhydride in n-Butane Oxidation, Using VPO Catalysts, was Improved Over the Years, Top. Catal., 57: 1188-1195.

Wang S.-L., C.-C. Wang and K.-H. Lii. 1989. Crystal structure of $\mathrm{WPO}_{5}$, the second member of the monophosphate tungsten bronze series $\left(\mathrm{WO}_{3}\right)_{2 \mathrm{~m}}\left(\mathrm{PO}_{2}\right)_{4}$, J. Solid State Chem., 82: 298-302.

Zazhigalov V. A., A. I. Pyatnitskaya, I. V. Bacherikova, G. A. Komashko, G. Ladwig and V. M. Belousov. 1983. Dependence of the activity of vanadium-phosphorus catalysts on the $\mathrm{V}^{4+} / \mathrm{V}^{5+}$ ratio in oxidation of butane, React. Kinet. Catal. Lett. 23: 119123.

Zubkov V., 1998. Inst. of Solid State Chemistry, Ekaterinburg, Russia, ICDD Grant-in-Aid, Powder Diffraction File-2.

(Received revised manuscript on 21 April 2019) 